\title{
COMPLEX EVALUATION OF THE ECONOMIC CRISIS IMPACT ON LITHUANIAN INDUSTRIES
}

\author{
Algirdas Krivka \\ Department of Economics and Management of Enterprises, \\ Vilnius Gediminas Technical University, Sauletekio al. 11, LT-10223 Vilnius, Lithuania \\ E-mail: algirdas.krivka@vgtu.lt
}

Received 13 July 2013; accepted 05 November 2013

\begin{abstract}
The paper analyses the impact of the economic crisis of 2008 on Lithuanian industries. The research involves 68 industries identified according to the 2nd-digit level classification of economic activities by Statistics Lithuania. Considering industry to be a complex phenomenon, the crisis effect is evaluated complexly on the basis of the system of 10 financial state and performance indicators belonging to four main groups of enterprise financial ratios: profitability, liquidity, solvency and asset turnover. SAW, TOPSIS and VIKOR multi-criteria decision making methods, widely applied in construction, economics and management, are selected as mathematical tools for quantitative assessment of the economic crisis effect on Lithuanian industries. By applying multi-criteria decision making methods relative positions (ranks) of industries are determined for every year of the period of 2006-2011. The ranks and their changes are further analysed distinguishing pre-crisis, crisis, and post-crisis periods, determining the industries most and least affected by the economic crisis; also, the industries characterised by the fastest and the slowest after-crisis recovery.
\end{abstract}

Keywords: industry research, economic crisis, financial ratios, financial indicators, multicriteria decision making, SAW, TOPSIS, VIKOR.

Reference to this paper should be made as follows: Krivka, A. 2014. Complex evaluation of the economic crisis impact on Lithuanian industries, Journal of Business Economics and management 15(2): 299-315.

JEL Classification: C44, G01, G11, G32, L25.

\section{Introduction}

Nowadays economic reality, characterised by growing countries' and regions' economic integration, globalization of business relations, free movement of capital and labour force, offers wide possibilities for the social and economic development of market economy countries and for increasing the welfare of their citizens. Expansion of financial markets together with growing banking sector assure the sources of financing business setting up and further development; diminishing barriers of international trade provide access to new markets for companies and satisfaction of growing needs for customers with a wide variety of goods and services. 
Although there is a little doubt about the advantages of international economic integration, a few recent years have shown in practice the other side of the coin. In 2007 the crisis, which initially affected the financial system of the United States, shortly spread all over the world and stimulated the economic recession, with both business and ordinary citizens suffering from its consequences (Thao et al. 2013; Kowalski 2012). In many countries the financial crisis caused a rapid decrease in tax revenues, while austerity measures in fiscal policy (raising taxes and cutting public spending) applied by governments even deepened the economic problems (Adam, Iacob 2012).

The Republic of Lithuania was amongst the countries to experience the deepest economic downturn: according to GDP data, the economic crisis, which started in the end of 2008, caused the fall of the annual GDP by $14.8 \%$ in 2009 (Statistics Lithuania 2013). It has to be admitted that deep recession was stimulated not only by the global economic crisis, but also by the internal specifics of the national economy evolution, and particularly because of the economy overheating and real estate price bubble caused by irresponsible lending and speculation. Though the first signs of economic recovery appeared in the $2^{\text {nd }}$ quarter of 2010 , the country's economic growth remained very slow during the last 3 years, while the GDP of 2012 is still under the pre-crisis level of 2007.

It has to be mentioned though, that GDP dynamics and other macroeconomic indicators provide general information only about the impact of the economic crisis, whereas even with a naked eye one may indicate the dissimilar effect of the crisis on various industries, also unequal rates of after-crisis recovery. Possibly uneven development of Lithuanian industries during the economic crisis of 2008 and afterwards, in the author's opinion, requires calculation-based evaluation with its results providing more detailed and scientifically grounded information about the impact of the recent crisis on business enterprises.

The problem of this paper is the complex quantitative evaluation of the economic crisis impact on industries. The aim of the research is to complexly evaluate the impact of the economic crisis of 2008 on Lithuanian industries on the basis of the system of quantitative indicators characterising enterprise's financial state and performance. Relying on scientific literature the system of industry research criteria is developed, while relative weights of the criteria are estimated by involving competent experts. By applying multi-criteria decision making methods (MCDM) relative positions (ranks) of Lithuanian industries are determined for every year of the period of 2006-2011. The ranks and their changes are further analysed distinguishing pre-crisis, crisis, and post-crisis periods, determining the industries most and least affected by the economic crisis; also, the industries characterised by the fastest and the slowest after-crisis recovery.

\section{Literature review}

Modern quantitative methods of enterprise performance analysis are based on the company's financial reports: horizontal analysis of enterprise financial statements studying accounts' dynamics during several periods; vertical analysis - a study of the structure of enterprise assets, equity and liabilities, and their changes; analysis of financial ratios - 
the indicators, characterising enterprise's financial state and performance, are calculated, compared through different accounting periods, between various companies, also with their recommended values (Hofmann, Lampe 2012; Erdogan 2013; Kotane, KuzminaMerlino 2012; Hegazy, M., Hegazy, S. 2012; Zelgalve, Zaharcenko 2012).

With an enterprise being a complex phenomenon for research, individual financial ratios are combined into complex (integrated) indicators in the research on bankrupt probability (Altman 1968; Bhunia, Sarkar 2011; Yap et al. 2010), complex evaluation of enterprise financial state and performance by applying multi-criteria evaluation methods (Ginevičius, Podviezko 2013; Hsu 2013; Hosseini et al. 2013). In strategic management models enterprise's financial indicators are complemented with qualitative criteria in order to complexly evaluate enterprise's strategic potential, calculate the results of strategy application (Ginevičius et al. 2012; Ginevičius, Krivka 2010; Punniyamoorthy, Murali 2008; Hegazy, M., Hegazy, S. 2012).

Analysis of enterprise financial indicators is also applicable for studying economic sectors or industries. The research of that kind deals with generalised (average) values of financial indicators of a group of enterprises or the whole industry assessing efficiency of companies' performance ( $\mathrm{Li}$ et al. 2011), studying the relation between enterprise performance and the value of its shares (Balatbat et al. 2010; Hosseini et al. 2013), performing comparative analysis of inter-industry performance or inter-state industries' evolution (Kotane, Kuzmina-Merlino 2012; Claudiu-Marian 2011; Hon, Chu 2011), implementing the research on the relations between enterprise size, organization structure, market share or market concentration, and performance (Hays et al. 2009; Uslayet al. 2010) and other research of the similar nature.

Industry performance analysis in the context of an economic crisis also deserves economists' attention during the recent few years; however, most of the researchers are concentrated on the particular sector of economy, industry or market, e.g. furniture industry (Li et al. 2011), textile (Abbas et al. 2012), banking sector (Romanova 2012; Lakštutienè et al. 2011), agriculture (Li et al. 2011), TFT-LCD panel industry (Hon, Chu 2011), automobile industry (Du 2009; Bok 2009), tourism (Baleanu et al. 2009), construction (Al-Malkawi 2013). Other scientists perform research on the economic crisis effect on small and medium enterprises (Yiannaki 2012; Soininen et al. 2012) or large publicly listed companies (Dzikowska, Jankowska 2012; Norvaišienė 2012; Hsu 2013).

Summarizing the literature analysis performed, absence of the detailed, complex research on the economic crisis effect on industries is discovered. With regards to the accomplished literature study, the author indicates a niche for the research on the economic crisis of 2008 impact on Lithuanian economy presented in this paper, which has to involve all the main industries, be based on quantitative criteria - the system of financial state and performance indicators - and integrated approach to industry, as a complex phenomenon, analysis, with support of widely recognized mathematical instruments applicable for complex quantitative evaluation. 


\section{Research scope and methodology}

The industries analysed in the paper are identified according to the $2^{\text {nd }}$-digit level classification of economic activities (based on NACE2) published by Statistics Lithuania (official national authority in the sphere of statistics). With regards to experience of other authors (Erdogan 2013; Kotane, Kuzmina-Merlino 2012; Balatbat et al. 2010; Hsu 2013; Hosseini et al. 2013; Abbas et al. 2012; Al-Malkawi 2013), the system of financial state and performance indicators is composed of four main groups of enterprise financial ratios: profitability, liquidity, solvency and asset turnover. The indicators selected for the research and their formulas are presented in Table 1.

Table 1. Financial state and performance indicators selected for the research and their formulas

\begin{tabular}{|c|c|c|}
\hline No & Indicators & Formulas \\
\hline \multicolumn{3}{|c|}{ Group A. Profitability indicators } \\
\hline 1 & Gross margin ratio & Gross profit / Sales revenues \\
\hline 2 & Return on sales (ROS) & Net profit / Sales revenues \\
\hline 3 & Return on assets (ROA) & Net profit / Total assets \\
\hline 4 & Return on equity (ROE) & Net profit / Equity \\
\hline \multicolumn{3}{|c|}{ Group B. Liquidity indicators } \\
\hline 5 & Current ratio & Current assets / Current liabilities \\
\hline 6 & Quick ratio & (Current assets - Inventory) / Current liabilities \\
\hline \multicolumn{3}{|c|}{ Group C. Solvency indicators } \\
\hline 7 & Equity-to-debt ratio & Equity / Total liabilities \\
\hline 8 & Debt ratio & Total liabilities / Total assets \\
\hline \multicolumn{3}{|c|}{ Group D. Asset turnover indicators } \\
\hline 9 & Total asset turnover & Sales revenues / Average total assets \\
\hline 10 & Accounts receivable turnover & Sales revenues / Average accounts receivable \\
\hline
\end{tabular}

The period of the research are the calendar years 2006-2011 including both pre-crisis, crisis and post-crisis years (at the moment of the research the data of 2012 had not been published yet). The research involves all the industries $\left(2^{\text {nd }}\right.$-digit level economic activities), which data is published by Statistics Lithuania (the list of the industries under research is provided further with the results of the research in Table 5), combining for $97.6 \%$ of Lithuanian enterprises (according to their value-added).

The complex quantitative evaluation of the economic crisis impact on Lithuanian industries is considered to be a mathematical problem of assessing the industries selected for the research with regards to the system of enterprise financial indicators as the evaluation criteria. To solve a problem of that kind, multi-criteria evaluation methods, developed throughout the recent years and widely applied in construction (e.g. Zavadskas et al. 2008; Ginevičius et al. 2008; Šaparauskas et al. 2011), economics and manage- 
ment (e.g. Ginevičius et al. 2012, 2013; Ginevičius, Podvezko 2008, 2009; Ginevičius, Podviezko 2011, 2013; Hsu 2013), seem to be an appropriate tool.

The alternatives under evaluation are 68 industries - each of them is assessed with regards to 10 financial state and performance indicators (the scheme of evaluation is presented in Table 2); the evaluation is performed for every year of the research period of 2006-2011. The value $r_{i j}$ of the particular evaluation criterion (financial indicator) $i(i=1, \ldots, m)$ for the assessed alternative (industry) $j(j=1, \ldots, n)$ is taken from the officially published data by Statistics Lithuania (2013). To estimate weights $\omega_{i}$ of the financial indicators, the method of expert evaluation is applied, with respect to the condition $\sum_{i=1}^{m} \omega_{i}=1$. The experts (financial directors or CEOs) were asked to provide a single set of criteria weights (showing the relative importance of the particular financial indicator) for the whole period of the research.

Table 2. The scheme of multi-criteria assessment of Lithuanian industries with regards to financial state and performance indicators

\begin{tabular}{|c|c|c|c|c|c|c|c|c|}
\hline \multicolumn{4}{|c|}{ Criteria } & \multicolumn{5}{|c|}{ Criteria values } \\
\hline No & Description & $\begin{array}{l}\operatorname{Max}(+) / \\
\operatorname{Min}(-)\end{array}$ & Weight & $\begin{array}{c}\text { Industry } \\
1\end{array}$ & $\cdots$ & $\begin{array}{l}\text { Industry } \\
\qquad j\end{array}$ & $\cdots$ & $\begin{array}{c}\text { Industry } \\
68\end{array}$ \\
\hline 1 & Gross margin ratio & + & $\omega_{1}$ & $r_{1,1}$ & $\cdots$ & $r_{1, j}$ & $\cdots$ & $r_{1,68}$ \\
\hline 2 & $\begin{array}{l}\text { Return on sales } \\
\text { (ROS) }\end{array}$ & + & $\cdots$ & $\ldots$ & & $\cdots$ & & $\cdots$ \\
\hline 3 & $\begin{array}{l}\text { Return on assets } \\
\text { (ROA) }\end{array}$ & + & $\cdots$ & $\cdots$ & & $\cdots$ & & $\cdots$ \\
\hline 4 & $\begin{array}{l}\text { Return on equity } \\
\text { (ROE) }\end{array}$ & + & $\cdots$ & $\cdots$ & & $\cdots$ & & $\cdots$ \\
\hline 5 & Current ratio & + & $\cdots$ & $\cdots$ & & $\cdots$ & & $\cdots$ \\
\hline 6 & Quick ratio & + & $\omega_{i}$ & $r_{i, 1}$ & $\cdots$ & $r_{i j}$ & $\cdots$ & $r_{i, 68}$ \\
\hline 7 & Equity-to-debt ratio & + & $\cdots$ & $\cdots$ & & $\cdots$ & & $\cdots$ \\
\hline 8 & Debt ratio & - & $\cdots$ & $\cdots$ & & $\cdots$ & & $\cdots$ \\
\hline 9 & Total asset turnover & + & $\cdots$ & $\cdots$ & & $\cdots$ & & $\cdots$ \\
\hline 10 & $\begin{array}{l}\text { Accounts receivable } \\
\text { turnover }\end{array}$ & + & $\omega_{10}$ & $r_{10,1}$ & $\cdots$ & $r_{10, j}$ & $\cdots$ & $r_{10,68}$ \\
\hline
\end{tabular}

The result of multi-criteria evaluation is the ranking of industries for every year of the period of 2006-2011. The further analysis is implemented studying the changes of the ranking to compare pre-crisis year of 2006, the crisis years of 2008-2009, and aftercrisis year of 2011 - the dynamics of the ranks reflect the impact of the crisis on the particular industry, including after-crisis recovery.

The experience of the recent research (e.g. Ginevičius, Podvezko 2009; Ginevičius et al. 2008, 2012; Ginevičius, Krivka 2010; Ginevičius, Podviezko 2011, 2013) suggests that 
the phenomenon under analysis has to be assessed by applying several multi-criteria methods seeking for higher reliability of results; moreover, in order to minimize the subjectivity of the specific method, average ranks are accepted to be the ultimate result. To efficiently combine several multi-criteria evaluation methods, it is important to form a "bunch" of correlating methods (Ginevičius, Podvezko 2008). SAW, TOPSIS and VIKOR methods are selected for multi-criteria assessment of Lithuanian industries.

SAW method calculates the sum of normalized weighted values $S_{j}$ of all criteria for each $j$-th alternative (Ginevičius et al. 2008, 2012, 2013; Podvezko 2011):

$$
S_{j}=\sum_{i=1}^{m} \omega_{i} \tilde{r}_{i j},
$$

while initial values are normalized using the formula (Ginevičius et al. 2008, 2012; Podvezko 2011):

$$
\tilde{r}_{i j}=\frac{r_{i j}}{\sum_{j=1}^{n} r_{i j}} .
$$

TOPSIS indicates the best $\left(V^{*}\right)$ and the worst $\left(V^{-}\right)$solutions with regards to each criterion (Opricovic, Tzeng 2004; Ginevičius et al. 2008):

$$
\begin{gathered}
V^{*}=\left\{V_{1}^{*}, V_{2}^{*}, \ldots, V_{m}^{*}\right\}=\left\{\left(\max _{j} \omega_{i} \tilde{r}_{i j} / i \in I_{1}\right),\left(\min _{j} \omega_{i} \tilde{r}_{i j} / i \in I_{2}\right)\right\}, \\
V^{-}=\left\{V_{1}^{-}, V_{2}^{-}, \ldots, V_{m}^{-}\right\}=\left\{\left(\min _{j} \omega_{i} \tilde{r}_{i j} / i \in I_{1}\right),\left(\max _{j} \omega_{i} \tilde{r}_{i j} / i \in I_{2}\right)\right\},
\end{gathered}
$$

where: $I_{1}$ is a set of maximizing criteria, $I_{2}$ is a set of minimizing criteria. The distance of each alternative to the best and the worst solutions is calculated:

$$
\begin{aligned}
& D_{j}^{*}=\sqrt{\sum_{i=1}^{m}\left(\omega_{i} \tilde{r}_{i j}-V_{i}^{*}\right)^{2}}, \\
& D_{j}^{-}=\sqrt{\sum_{i=1}^{m}\left(\omega_{i} \tilde{r}_{i j}-V_{i}^{-}\right)^{2}},
\end{aligned}
$$

followed by the TOPSIS criterion, which maximum value (i.e. the value which is closest to 1) corresponds to the best alternative:

$$
C_{j}^{*}=\frac{D_{j}^{-}}{D_{j}^{*}+D_{j}^{-}} .
$$

The initial values $r_{i j}$ are normalized by applying the vector normalization formula (Ginevičius et al. 2008, 2012):

$$
\tilde{r}_{i j}=\frac{r_{i j}}{\sqrt{\sum_{j=1}^{n} r_{i j}^{2}}} .
$$

VIKOR is based on the three evaluation criteria $S_{j}, R_{j}$ and $Q_{j}$, calculated by the following formulas (Opricovic, Tzeng 2004; Ginevičius et al. 2008): 


$$
\begin{gathered}
S_{j}=\sum_{i=1}^{m} \omega_{i} \tilde{r}_{i j}, \\
R_{j}=\max _{i}\left(\omega_{i} \tilde{r}_{i j}\right), \\
Q_{j}=v \frac{S_{j}-S^{*}}{S^{-}-S^{*}}+(1-v) \frac{R_{j}-R^{*}}{R^{-}-R^{*}},
\end{gathered}
$$

where: $S^{*}=\min _{j} S_{j}, S^{-}=\max _{j} S_{j}, R^{*}=\min _{j} R_{j}, R^{-}=\max _{j} R_{j}, v$ is the majority criterion, equalled to 0.5 in empiric research (e.g. Ginevičius, Krivka 2010). The lowest values of $Q_{j}$ indicate the best alternatives.

Normalization of maximizing criteria values is performed by applying the formula:

$$
\tilde{r}_{i j}=\frac{\max _{j} r_{i j}-r_{i j}}{\max _{j} r_{i j}-\min _{j} r_{i j}} .
$$

Where negative values are involved in multi-criteria assessment, they are transformed into positive by adding the shifting constant $b_{i}$ to each value $r_{i j}$ of the $i$-th criterion having at least one negative value (Podvezko 2011):

$$
\bar{r}_{i j}=r_{i j}+b_{i} \text {. }
$$

For the shifting procedure to have the least possible effect on evaluation results, minimum values of the shifting constant are considered, calculated as follows:

$$
b_{i}=\left|\min _{j} r_{i j}\right|+0.01 \text {. }
$$

\section{Research procedure and results}

The questionnaires for estimating weights of the selected financial state and performance indicators (evaluation criteria) were submitted to 80 enterprises. The experts (financial directors or CEOs) were asked to evaluate weights of the financial indicators in two steps: first the weights of the indicators inside every particular group (see Table 1) were estimated; then the weights of the groups (profitability, liquidity, solvency and asset turnover) in the integrated criterion were determined. The ultimate weight $\omega_{i}$ of the $i$-th indicator was calculated by multiplying its weight $\omega_{i}^{g}$ inside the group by the weight $\omega_{g}$ of the group in the integrated criterion:

$$
\omega_{i}=\omega_{i}^{g} \cdot \omega_{g},
$$

with respect to the conditions: $\sum \omega_{i}^{g}=1$ (for every group of indicators) and $\sum \omega_{g}=1$ (for the integrated criterion).

Such practice was addressed in order to simplify evaluation procedure and to avoid unintentional overweighting of profitability indicators, which could occur in case of direct evaluation just because of the number of indicators in profitability group (4 indicators) compared to other groups consisting of 2 indicators. 
Table 3. Evaluation criteria weights based on expert estimates

\begin{tabular}{llcccccccccc}
\hline \multicolumn{1}{l}{ Evaluation criteria } & \multicolumn{1}{c}{ Experts and criteria weights } \\
\hline No & \multicolumn{1}{c}{ Description } & 1 & 2 & 3 & 4 & 5 & 6 & 7 & 8 & 9 & Average \\
\hline 1 & Gross margin ratio & 0.053 & 0.060 & 0.080 & 0.063 & 0.060 & 0.160 & 0.098 & 0.075 & 0.140 & 0.081 \\
\hline 2 & $\begin{array}{l}\text { Return on sales } \\
\text { (ROS) }\end{array}$ & 0.140 & 0.090 & 0.160 & 0.088 & 0.150 & 0.040 & 0.338 & 0.105 & 0.420 & 0.139 \\
\hline 3 & $\begin{array}{l}\text { Return on assets } \\
\text { (ROA) }\end{array}$ & 0.018 & 0.075 & 0.040 & 0.038 & 0.030 & 0.100 & 0.005 & 0.045 & 0.035 & 0.044 \\
\hline 4 & $\begin{array}{l}\text { Return on equity } \\
\text { (ROE) }\end{array}$ & 0.140 & 0.075 & 0.120 & 0.063 & 0.060 & 0.100 & 0.049 & 0.075 & 0.105 & 0.085 \\
\hline 5 & Current ratio & 0.060 & 0.120 & 0.060 & 0.100 & 0.080 & 0.060 & 0.004 & 0.140 & 0.128 & 0.078 \\
\hline 6 & Quick ratio & 0.090 & 0.180 & 0.090 & 0.150 & 0.120 & 0.090 & 0.006 & 0.210 & 0.023 & 0.117 \\
\hline 7 & Equity-to-debt ratio & 0.090 & 0.100 & 0.150 & 0.210 & 0.110 & 0.090 & 0.050 & 0.098 & 0.050 & 0.112 \\
\hline 8 & Debt ratio & 0.210 & 0.100 & 0.150 & 0.140 & 0.090 & 0.060 & 0.050 & 0.053 & 0.050 & 0.107 \\
\hline 9 & Total asset turnover & 0.140 & 0.080 & 0.105 & 0.090 & 0.240 & 0.180 & 0.320 & 0.140 & 0.035 & 0.162 \\
\hline 10 & $\begin{array}{l}\text { Accounts receivable } \\
\text { turnover }\end{array}$ & 0.060 & 0.120 & 0.045 & 0.060 & 0.060 & 0.120 & 0.080 & 0.060 & 0.015 & 0.076 \\
\hline & Totals & 1.000 & 1.000 & 1.000 & 1.000 & 1.000 & 1.000 & 1.000 & 1.000 & 1.000 & 1.000 \\
\hline
\end{tabular}

Nine answers with fully and accurately filled questionnaires were received to provide data for calculating the ultimate criteria weights (Table 3).

The concordance coefficient, calculated as the ratio of actual $(S)$ and ideal $\left(S_{\max }\right)$ dispersions, is applied to check the degree of agreement of expert estimates (Kendall 1970; Ginevičius et al. 2008):

$$
W=\frac{S}{S_{\max }}=\frac{12 S}{r^{2} m\left(m^{2}-1\right)},
$$

while the actual dispersion is calculated by the formula:

$$
S=\sum_{i=1}^{m}\left(c_{i}-\bar{c}\right)^{2}
$$

where: $c_{i}$ is the sum of ranks of all $r$ experts' criterion $i$ estimates, $\bar{c}$ is the mean value of sums of all criteria $(i=1, \ldots, m)$ ranks. The consistency of estimates is tested by $\chi^{2}$ distribution with $v=m-1$ degrees of freedom:

$$
\chi^{2}=W r(m-1)=\frac{12 S}{r m(m+1)} .
$$

Whereas the calculated value of $\chi^{2}=21.01$ is larger than the critical value of $\chi_{c r}^{2}=16.92$ (with the significance level of $\alpha=0.05$ and 9 degrees of freedom), the expert estimates are considered to be in agreement, while the average weights are employed for multicriteria assessment of Lithuanian industries. 
For every year of the research (2006-2011) the ranks of the industries are calculated by applying the three chosen MCDM methods: SAW, TOPSIS and VIKOR. The test for correlation of the results obtained (Table 4) discloses diverging results of VIKOR, with the correlation coefficient (modulus value) with SAW being less than 0.8 . Thus, only SAW and TOPSIS methods are considered for ultimate ranking of the industries.

Table 4. Correlation of the results of multi-criteria evaluation

\begin{tabular}{ccc}
\hline & TOPSIS & VIKOR \\
\hline SAW & 0.923 & -0.618 \\
\hline
\end{tabular}

The ultimate ranks of Lithuanian industries, presented in Table 5, are the average results obtained by SAW and TOPSIS. Absolute changes of the rank compared to pre-crisis year of 2006 are further calculated: a positive change discloses the improvement of the relative position of the industry, while a negative change corresponds to the fall of the rank.

Table 5. The ultimate ranks of the industries and their changes compared to 2006

\begin{tabular}{|c|c|c|c|c|c|c|c|c|c|c|c|}
\hline \multirow{3}{*}{ Industries } & \multicolumn{11}{|c|}{ Ranking } \\
\hline & \multicolumn{6}{|c|}{ Ultimate ranks } & \multicolumn{5}{|c|}{$\begin{array}{l}\text { Rank absolute changes } \\
\text { compared to } 2006\end{array}$} \\
\hline & 2006 & 2007 & 2008 & 2009 & 2010 & 2011 & 2007 & 2008 & 2009 & 2010 & 2011 \\
\hline 1 & 2 & 3 & 4 & 5 & 6 & 7 & 8 & 9 & 10 & 11 & 12 \\
\hline A02 Forestry and logging & 6 & 4 & 10 & 5 & 4 & 5 & 2 & -4 & 1 & 2 & 1 \\
\hline $\begin{array}{l}\text { A03 Fishing and } \\
\text { aquaculture }\end{array}$ & 41 & 60 & 20 & 35 & 61 & 62 & -19 & 21 & 6 & -20 & -21 \\
\hline $\begin{array}{l}\text { B06 Extraction of crude } \\
\text { petroleum and natural gas }\end{array}$ & 2 & 5 & 2 & 2 & 2 & 4 & -3 & 0 & 0 & 0 & -2 \\
\hline $\begin{array}{l}\text { B08 Other mining and } \\
\text { quarrying }\end{array}$ & 15 & 14 & 15 & 45 & 48 & 32 & 1 & 0 & -30 & -33 & -17 \\
\hline $\begin{array}{l}\text { C10 Manufacture of food } \\
\text { products }\end{array}$ & 62 & 44 & 52 & 28 & 34 & 50 & 18 & 10 & 34 & 28 & 12 \\
\hline $\begin{array}{l}\text { C11 Manufacture of } \\
\text { beverages }\end{array}$ & 25 & 26 & 24 & 24 & 47 & 44 & -1 & 1 & 1 & -22 & -19 \\
\hline C13 Manufacture of textiles & 65 & 65 & 65 & 54 & 53 & 32 & 0 & 0 & 11 & 12 & 33 \\
\hline $\begin{array}{l}\text { C14 Manufacture of } \\
\text { wearing apparel }\end{array}$ & 48 & 50 & 48 & 38 & 36 & 21 & -2 & 0 & 10 & 12 & 27 \\
\hline $\begin{array}{l}\text { C15 Manufacture of leather } \\
\text { and related products }\end{array}$ & 43 & 67 & 53 & 58 & 58 & 65 & -24 & -10 & -15 & -15 & -22 \\
\hline $\begin{array}{l}\text { C16 Manufacture of wood } \\
\text { and of products of wood } \\
\text { and cork, except furniture; } \\
\text { manufacture of articles of } \\
\text { straw and plaiting materials }\end{array}$ & 63 & 53 & 68 & 62 & 55 & 59 & 10 & -5 & 1 & 8 & 4 \\
\hline
\end{tabular}


Continue of Table 5

\begin{tabular}{lccccccccccc}
\hline \multicolumn{1}{c}{1} & 2 & 3 & 4 & 5 & 6 & 7 & 8 & 9 & 10 & 11 & 12 \\
\hline $\begin{array}{l}\text { C17 Manufacture of paper } \\
\text { and paper products }\end{array}$ & 55 & 58 & 62 & 55 & 42 & 55 & -3 & -7 & 0 & 13 & 0 \\
\hline $\begin{array}{l}\text { C18 Printing and } \\
\text { reproduction of recorded } \\
\text { media }\end{array}$ & 39 & 59 & 52 & 43 & 44 & 30 & -20 & -13 & -4 & -5 & 9 \\
\hline
\end{tabular}

C20 Manufacture of chemicals and chemical

$\begin{array}{lllllllllll}51 & 38 & 28 & 20 & 12 & 9 & 13 & 23 & 31 & 39 & 42\end{array}$
products

\begin{tabular}{llllllllllll}
\hline C21 Manufacture of basic & 35 & 16 & 36 & 24 & 11 & 25 & 19 & -1 & 11 & 24 & 10
\end{tabular}
pharmaceutical products

and pharmaceutical

preparations

\begin{tabular}{lccccccccccc}
\hline $\begin{array}{l}\text { C22 Manufacture of rubber } \\
\text { and plastic products }\end{array}$ & 52 & 52 & 59 & 54 & 51 & 54 & 0 & -7 & -2 & 1 & -2 \\
\hline $\begin{array}{l}\text { C23 Manufacture of other } \\
\text { non-metallic mineral } \\
\text { products }\end{array}$ & 28 & 28 & 36 & 49 & 56 & 61 & 0 & -8 & -21 & -28 & -33 \\
\hline
\end{tabular}

\begin{tabular}{llllllllllll}
\hline C24 Manufacture of basic & 39 & 59 & 33 & 52 & 63 & 44 & -20 & 6 & -13 & -24 & -5
\end{tabular}
metals

\begin{tabular}{llllllllllll}
\hline $\begin{array}{l}\text { C25 Manufacture of } \\
\text { fabricated metal products, } \\
\text { except machinery and } \\
\text { equipment }\end{array}$ & 50 & 46 & 51 & 45 & 51 & 46 & 4 & -1 & 5 & -1 & 4 \\
\hline
\end{tabular}

\begin{tabular}{llllllllllll}
\hline C26 Manufacture of & 68 & 66 & 28 & 38 & 28 & 37 & 2 & 40 & 30 & 40 & 31
\end{tabular}
computer, electronic and optical products

\begin{tabular}{lccccccccccc}
\hline $\begin{array}{l}\text { C27 Manufacture of } \\
\text { electrical equipment }\end{array}$ & 63 & 60 & 58 & 62 & 46 & 39 & 3 & 5 & 1 & 17 & 24 \\
\hline $\begin{array}{l}\text { C28 Manufacture of } \\
\text { machinery and equipment }\end{array}$ & 36 & 46 & 32 & 27 & 26 & 34 & -10 & 4 & 9 & 10 & 2 \\
n.e.c. & & & & & & & & & & & \\
\hline $\begin{array}{l}\text { C29 Manufacture of motor } \\
\text { vehicles, trailers and semi- } \\
\text { trailers }\end{array}$ & 8 & 35 & 15 & 8 & 8 & 10 & -27 & -7 & 0 & 0 & -2 \\
\end{tabular}

\begin{tabular}{lccccccccccc}
\hline $\begin{array}{l}\text { C30 Manufacture of other } \\
\text { transport equipment }\end{array}$ & 32 & 27 & 25 & 18 & 6 & 26 & 5 & 7 & 14 & 26 & 6 \\
\hline C31 Manufacture of & 63 & 35 & 46 & 33 & 36 & 35 & 28 & 17 & 30 & 27 & 28
\end{tabular}
furniture

\begin{tabular}{llllllllllll}
\hline C32 Other manufacturing & 30 & 49 & 36 & 35 & 30 & 51 & -19 & -6 & -5 & 0 & -21 \\
\hline $\begin{array}{l}\text { C33 Repair and installation } \\
\text { of machinery and }\end{array}$ & 22 & 40 & 36 & 33 & 39 & 58 & -18 & -14 & -11 & -17 & -36 \\
equipment & & & & & & & & & & & \\
\hline
\end{tabular}

\begin{tabular}{llllllllllll}
\hline D35 Electricity, gas, steam & 20 & 18 & 20 & 16 & 23 & 43 & 2 & 0 & 4 & -3 & -23
\end{tabular} and air conditioning supply

\begin{tabular}{llllllllllllll}
\hline $\begin{array}{l}\text { E36 Water collection, } \\
\text { treatment and supply }\end{array}$ & 7 & 8 & 9 & 5 & 5 & 11 & -1 & -2 & 2 & 2 & -4 \\
\hline
\end{tabular}


Continue of Table 5

\begin{tabular}{lccccccccccc}
\hline \multicolumn{1}{c}{1} & 2 & 3 & 4 & 5 & 6 & 7 & 8 & 9 & 10 & 11 & 12 \\
\hline $\begin{array}{l}\text { E38 Waste collection, } \\
\text { treatment and disposal } \\
\begin{array}{l}\text { activities; materials } \\
\text { recovery }\end{array}\end{array}$ & 53 & 62 & 52 & 42 & 24 & 31 & -9 & 1 & 11 & 29 & 22 \\
\hline $\begin{array}{l}\text { F41 Construction of } \\
\text { buildings }\end{array}$ & 49 & 57 & 65 & 68 & 67 & 68 & -8 & -16 & -19 & -18 & -19 \\
\hline F42 Civil engineering & 40 & 47 & 43 & 49 & 42 & 66 & -7 & -3 & -9 & -2 & -26 \\
\hline $\begin{array}{l}\text { F43 Specialised } \\
\text { construction activities }\end{array}$ & 37 & 36 & 50 & 61 & 60 & 58 & 1 & -13 & -24 & -23 & -21 \\
\hline $\begin{array}{l}\text { G45 Wholesale and retail } \\
\text { trade and repair of motor } \\
\text { vehicles and motorcycles }\end{array}$ & 24 & 15 & 50 & 52 & 44 & 29 & 9 & -26 & -28 & -20 & -5 \\
\hline $\begin{array}{l}\text { G46 Wholesale trade, } \\
\text { except of motor vehicles } \\
\text { and motorcycles }\end{array}$ & 47 & 37 & 45 & 44 & 41 & 48 & 10 & 2 & 3 & 6 & -1 \\
\hline
\end{tabular}

\begin{tabular}{llllllllllll}
\hline G47 Retail trade, except & 17 & 18 & 17 & 6 & 10 & 11 & -1 & 0 & 11 & 7 & 6
\end{tabular}
of motor vehicles and motorcycles

\begin{tabular}{|c|c|c|c|c|c|c|c|c|c|c|c|}
\hline $\begin{array}{l}\text { H49 Land transport and } \\
\text { transport via pipelines }\end{array}$ & 30 & 37 & 52 & 50 & 42 & 40 & -7 & -22 & -20 & -12 & -10 \\
\hline H50 Water transport & 6 & 10 & 8 & 13 & 25 & 66 & -4 & -2 & -7 & -19 & -60 \\
\hline H51 Air transport & 61 & 28 & 5 & 28 & 64 & 50 & 33 & 56 & 33 & -3 & 11 \\
\hline $\begin{array}{l}\text { H52 Warehousing and } \\
\text { support activities for } \\
\text { transportation }\end{array}$ & 37 & 40 & 31 & 28 & 25 & 24 & -3 & 6 & 9 & 12 & 13 \\
\hline $\begin{array}{l}\text { H53 Postal and courier } \\
\text { activities }\end{array}$ & 22 & 36 & 41 & 49 & 54 & 37 & -14 & -19 & -27 & -32 & -15 \\
\hline I55 Accommodation & 48 & 32 & 68 & 38 & 65 & 45 & 16 & -20 & 10 & -17 & 3 \\
\hline $\begin{array}{l}\text { I56 Food and beverage } \\
\text { service activities }\end{array}$ & 39 & 34 & 63 & 36 & 42 & 17 & 5 & -24 & 3 & -3 & 22 \\
\hline J58 Publishing activities & 48 & 46 & 48 & 36 & 46 & 54 & 2 & 0 & 12 & 2 & -6 \\
\hline $\begin{array}{l}\text { J59 Motion picture, video } \\
\text { and television programme } \\
\text { production, sound recording } \\
\text { and music publishing } \\
\text { activities }\end{array}$ & 60 & 57 & 56 & 65 & 39 & 55 & 3 & 4 & -5 & 21 & 5 \\
\hline $\begin{array}{l}\text { J60 Programming and } \\
\text { broadcasting activities }\end{array}$ & 13 & 15 & 6 & 24 & 23 & 43 & -2 & 7 & -11 & -10 & -30 \\
\hline J61 Telecommunications & 4 & 21 & 20 & 17 & 18 & 18 & -17 & -16 & -13 & -14 & -14 \\
\hline $\begin{array}{l}\text { J62 Computer } \\
\text { programming, consultancy } \\
\text { and related activities }\end{array}$ & 29 & 25 & 23 & 46 & 26 & 22 & 4 & 6 & -17 & 3 & 7 \\
\hline $\begin{array}{l}\text { J63 Information service } \\
\text { activities }\end{array}$ & 11 & 10 & 11 & 17 & 17 & 16 & 1 & 0 & -6 & -6 & -5 \\
\hline
\end{tabular}


End of Table 5

\begin{tabular}{lccccccccccc}
\hline \multicolumn{1}{c}{1} & 2 & 3 & 4 & 5 & 6 & 7 & 8 & 9 & 10 & 11 & 12 \\
\hline L68 Real estate activities & 6 & 28 & 66 & 66 & 64 & 50 & -22 & -60 & -60 & -58 & -44 \\
\hline $\begin{array}{l}\text { M69 Legal and accounting } \\
\text { activities }\end{array}$ & 20 & 32 & 40 & 31 & 33 & 17 & -12 & -20 & -11 & -13 & 3 \\
\hline $\begin{array}{l}\text { M70 Activities of head } \\
\text { offices; management } \\
\text { consultancy activities }\end{array}$ & 8 & 1 & 5 & 4 & 4 & 2 & 7 & 3 & 4 & 4 & 6 \\
\hline $\begin{array}{l}\text { M71 Architectural and } \\
\text { engineering activities; } \\
\text { technical testing and } \\
\text { analysis }\end{array}$ & 33 & 36 & 30 & 29 & 27 & 29 & -3 & 3 & 4 & 6 & 4 \\
\hline
\end{tabular}

\begin{tabular}{llllllllllll}
\hline M72 Scientific research and & 20 & 14 & 10 & 11 & 17 & 36 & 6 & 10 & 9 & 3 & -16
\end{tabular} development

\begin{tabular}{llllllllllll}
\hline $\begin{array}{l}\text { M73 Advertising and } \\
\text { market research }\end{array}$ & 42 & 27 & 41 & 50 & 52 & 42 & 15 & 1 & -8 & -10 & 0 \\
\hline
\end{tabular}

\begin{tabular}{llllllllllll}
\hline M74 Other professional, & 62 & 54 & 49 & 48 & 57 & 36 & 8 & 13 & 14 & 5 & 26
\end{tabular}
scientific and technical activities

\begin{tabular}{|c|c|c|c|c|c|c|c|c|c|c|c|}
\hline M75 Veterinary activities & 11 & 13 & 13 & 12 & 9 & 6 & -2 & -2 & -1 & 2 & 5 \\
\hline $\begin{array}{l}\text { N77 Rental and leasing } \\
\text { activities }\end{array}$ & 54 & 47 & 49 & 68 & 67 & 39 & 7 & 5 & -14 & -13 & 15 \\
\hline N78 Employment activities & 25 & 11 & 15 & 10 & 10 & 12 & 14 & 10 & 15 & 15 & 13 \\
\hline $\begin{array}{l}\text { N79 Travel agency, tour } \\
\text { operator reservation service } \\
\text { and related activities }\end{array}$ & 14 & 10 & 21 & 9 & 16 & 11 & 4 & -7 & 5 & -2 & 3 \\
\hline $\begin{array}{l}\text { N80 Security and } \\
\text { investigation activities }\end{array}$ & 16 & 23 & 17 & 13 & 19 & 36 & -7 & -1 & 3 & -3 & -20 \\
\hline $\begin{array}{l}\text { N81 Services to buildings } \\
\text { and landscape activities }\end{array}$ & 2 & 2 & 3 & 1 & 1 & 1 & 0 & -1 & 1 & 1 & 1 \\
\hline $\begin{array}{l}\text { N82 Office administrative, } \\
\text { office support and other } \\
\text { business support activities }\end{array}$ & 25 & 32 & 37 & 47 & 26 & 24 & -7 & -12 & -22 & -1 & 1 \\
\hline P85 Education & 17 & 18 & 20 & 13 & 13 & 15 & -1 & -3 & 4 & 4 & 2 \\
\hline $\begin{array}{l}\text { Q86 Human health } \\
\text { activities }\end{array}$ & 35 & 17 & 21 & 21 & 14 & 16 & 18 & 14 & 14 & 21 & 19 \\
\hline $\begin{array}{l}\text { R90 Creative, arts and } \\
\text { entertainment activities }\end{array}$ & 59 & 32 & 60 & 55 & 38 & 46 & 27 & -1 & 4 & 21 & 13 \\
\hline $\begin{array}{l}\text { R93 Sports activities and } \\
\text { amusement and recreation } \\
\text { activities }\end{array}$ & 67 & 68 & 2 & 57 & 59 & 4 & -1 & 65 & 10 & 8 & 63 \\
\hline $\begin{array}{l}\text { S95 Repair of computers } \\
\text { and personal and household } \\
\text { goods }\end{array}$ & 49 & 45 & 38 & 29 & 28 & 36 & 4 & 11 & 20 & 21 & 13 \\
\hline $\begin{array}{l}\text { S96 Other personal service } \\
\text { activities }\end{array}$ & 57 & 62 & 52 & 53 & 63 & 66 & -5 & 5 & 4 & -6 & -9 \\
\hline
\end{tabular}


The changes of the ranks in the years 2008-2009 compared to pre-crisis year of 2006 are supposed to indicate the industries most and least affected by the economic crisis. The further dynamics of the ranks, particularly in 2011, allow determining the industries characterised by the fastest and the slowest after-crisis recovery, also indicate the changes of the ranking during the whole period of the research (2006-2011).

The most affected by the economic crisis industries are considered to be L68 Real estate activities (significant fall of the rank from the $6^{\text {th }}$ in 2006 to the $66^{\text {th }}$ in 2008-2009); G45 Wholesale and retail trade and repair of motor vehicles and motorcycles, H53 Postal and courier activities, H49 Land transport and transport via pipelines - three industries falling by 20 or more positions in the ranking during the crisis; F43 Specialised construction activities, F41 Construction of buildings, N82 Office administrative, office support and other business support activities, M69 Legal and accounting activities, B08 Other mining and quarrying, C23 Manufacture of other non-metallic mineral products, J61 Telecommunications - all falling by $15-19$ positions in the industries' ranking in 2008-2009 compared to 2006.

The least affected by the crisis industries are H51 Air transport, R93 Sports activities and amusement and recreation activities, C26 Manufacture of computer, electronic and optical products, C20 Manufacture of chemicals and chemical products, C31 Manufacture of furniture, C10 Manufacture of food products - all experiencing the rise of the rank by at least 20 positions during the crisis compared to 2006; also, Q86 Human health activities, M74 Other professional, scientific andtechnical activities, A03 Fishing and aquaculture, N78 Employment activities, C30 Manufacture of other transport equipment, M72 Scientific research and development - rising by 10 or more positions in the ranking.

By comparing the ranks of 2011 (post-crisis period) to 2008-2009 (the years of the deepest crisis) industries' after-crisis recovery is analysed. The fastest recovery, considering the industries significantly affected by the crisis, appeared in I56 Food and beverage service activities, G45 Wholesale and retail trade and repair of motor vehicles and motorcycles, M69 Legal and accounting activities, N82 Office administrative, office support and other business support activities, L68 Real estate activities and H49 Land transport and transport via pipelines. On the other hand the list of crisis-affected industries, which even worsened their relative position comparing 2011 to 2008-2009, includes C33 Repair and installation of machinery and equipment, C23 Manufacture of other non-metallic mineral products, $\mathrm{C} 15$ Manufacture of leather and related products and F41 Construction of buildings.

Considering the whole period of the research (2006-2011), which includes pre-crisis, crisis and post-crisis years, the main changes in the ranking of Lithuanian industries due to the recent economic cycles are further indicated. The most appreciable improvement of the rank is noticed to be in R93 Sports activities and amusement and recreation activities ( +63 positions), C20 Manufacture of chemicals and chemical products $(+42)$, C13 Manufacture of textiles (+33), C26 Manufacture of computer, electronic and optical products (+31), C31 Manufacture of furniture (+28), C14 Manufacture of wearing 
apparel $(+27)$ and M74 Other professional, scientific and technical activities $(+26)$; while a significant fall of the rank is determined in H50 Water transport (-60), L68 Real estate activities (-44), C33 Repair and installation of machinery and equipment $(-36)$, C23 Manufacture of other non-metallic mineral products (-33), J60 Programming and broadcasting activities (-30) and F42 Civil engineering (-26).

Finally, the average ranks of the industries in the period of 2006-2011 are compared, identifying the best and worst performing industries during the recent economic cycles. The top industries according to their average ranks are N81 Services to buildings andlandscape activities, B06 Extraction of crude petroleum and natural gas, M70 Activities of head offices; management consultancy activities, A02 Forestry and logging, E36 Water collection, treatment and supply, M75 Veterinary activities, G47 Retail trade, except of motor vehicles and motorcycles and N79 Travel agency, tour operator reservation service and related activities, J63 Information service activities and N78 Employment activities; while the worst performing industries are supposed to be F41 Construction of buildings, C16 Manufacture of wood and of products of wood and cork, except furniture; manufacture of articles of straw and plaiting materials, S96 Other personal service activities, C15 Manufacture of leather and related products, C13 Manufacture of textiles, J59 Motion picture, video and television programme production, sound recording and music publishing activities, C27 Manufacture of electrical equipment, C17 Manufacture of paper and paper products, N77 Rental and leasing activities and C22 Manufacture of rubber and plastic products.

\section{Conclusions}

The paper presents the empiric research on the impact of the economic crisis of 2008 on Lithuanian industries. The research has involved 68 industries, while the crisis effect has been evaluated on the basis of the system of 10 financial state and performance indicators belonging to four main groups of enterprise financial ratios: profitability, liquidity, solvency and asset turnover.

According to the research methodology, considering the integrated approach to industry as a complex phenomenon, the problem of complex evaluation of the economic crisis impact has been formalised as the comparative quantitative assessment of the industries (alternatives for evaluation) with regards to the chosen financial state and performance indicators (evaluation criteria). Multi-criteria decision making methods SAW, TOPSIS and VIKOR, widely applied in the recent research for evaluating complex economic phenomena, have been chosen as the tool for evaluation. Considering low correlation of the results between SAW and VIKOR, the latter MCDM method has been rejected, with ultimate ranks being the average of SAW and TOPSIS.

By analysing the changes of the ranks in 2008-2009 compared to pre-crisis year of 2006, the industries most and least affected by the economic crisis have been indicated. Furthermore, the ranks of post-crisis year of 2011 have been compared to 2008-2009, and the industries characterised by the fastest and the slowest after-crisis recovery have been identified. 
Considering the whole period of the research (2006-2011), which includes pre-crisis, crisis and post-crisis years, the most improved industries, as well as the ones with the deepest fall of the rank, have been determined. Finally, the average ranks of the industries during the period of 2006-2011 have been compared identifying the industries being on the top and in the bottom of the list according to their performance indicators.

The results of the research from the practical point of view might be useful for potential investors while choosing the particular industries or enterprises for long-term investment, also for government authorities involved in forming and implementing economic policy. For other researchers the approach and methodology of the research might seem interesting, as well as the results obtained.

\section{References}

Abbas, F.; Tahir, M.; Rehman, M. U.; Perviz, A. 2012. Impact of financial crisis on textile industry in Pakistan, Information Management and Business Review 4(7): 409-416.

Adam, A.; Iacob, S. E. 2012. Consequences and possible solutions of financial crisis, Theoretical and Applied Economics 12(577): 143-148.

Al-Malkawi, H.-A. N. 2013. The impact of financial crisis on UAE real estate and construction sector: analysis and implications, Humanomics 29(2): 115-135.

http://dx.doi.org/10.1108/08288661311319184

Altman, E. I. 1968. Financial ratios, discriminant analysis and the prediction of corporate bankruptcy, Journal of Finance 23(4): 589-609. http://dx.doi.org/10.1111/j.1540-6261.1968.tb00843.x

Balatbat, M. C. A.; Lin, C.; Carmichael, D. G. 2010. Comparative performance of publicly listed construction companies: Australian evidence, Construction Management and Economics 28: 919-932. http://dx.doi.org/10.1080/01446193.2010.501805

Baleanu, V.; Ionica, A.; Irimie, S. 2009. Exploring tourism dynamics: challenges in times of crisis, Annals of the University of Petroşani, Economics 9(3): 33-40.

Bhunia, A.; Sarkar, R. 2011. A study of financial distress based on MDA, Journal of Management Research 3(2): 1-11. http://dx.doi.org/10.5296/jmr.v3i2.549

Bok, D.-K. 2009. Changes and determinants of suppliers' customer scope in the Korean automobile industry after the Asian financial crisis, Global Economic Review 38(3): 321-332.

http://dx.doi.org/10.1080/12265080903157367

Claudiu-Marian, G. 2011. The financial performance of European companies: a comparative approach. University of Oradea, Faculty of Economics, Annals of Faculty of Economics 1: 193-200.

Du, L. 2009. An analysis on transnational investment of China's automobile industry under the financial crisis, International Journal of Marketing Studies 1(2): 18-22.

Dzikowska, M.; Jankowska, B. 2012.The global financial crisis of 2008-2009 and the fortune global 500 corporations. Looking for losers among the biggest - exploratory study, Poznan University of Economics Review 12(3): 99-124.

Erdogan, A. I. 2013. Applying factor analysis on the financial ratios of Turkey's top 500 industrial enterprises, International Journal of Business and Management 8(9): 134-139.

http://dx.doi.org/10.5539/ijbm.v8n9p134

Ginevičius, R.; Krivka, A. 2010. The model of the integrated competitive strategy of an enterprise under the conditions of oligopolic market, in 6th International Conference "Business and Management 2010”, May 13-14, Vilnius: 985-992. 
Ginevičius, R.; Podvezko, V. 2008. Multicriteria graphical-analytical evaluation of the financial state of construction enterprises, Baltic Journal of Sustainability 14(4): 452-461.

Ginevičius, R.; Podvezko, V. 2009. Evaluating the changes in economic and social development of Lithuanian counties by multiple criteria methods, Technological and Economic Development of Economy 15(3): 418-436. http://dx.doi.org/10.3846/1392-8619.2009.15.418-436

Ginevičius, R.; Podvezko, V.; Raslanas, S. 2008. Evaluating the alternative solutions of wall insulation by multicriteria methods, Journal of Civil Engineering and Management 14(4): 217-226. http://dx.doi.org/10.3846/1392-3730.2008.14.20

Ginevičius, R.; Podvezko, V.; Ginevičius, A. 2013. Quantitative evaluation of enterprise marketing activities, Journal of Business Economics and Management 14(1): 200-212.

http://dx.doi.org/10.3846/1611-1699.2008.9.167-180

Ginevičius, R.; Podvezko, V.; Novotny, M.; Komka, A. 2012. Comprehensive quantitative evaluation of the strategic potential of an enterprise, Economic Computation and Economic Cybernetics Studies and Research 46(1): 65-84.

Ginevičius, R.; Podviezko, A. 2011. A framework of evaluation of commercial banks, Intellectual Economics 1(9): 37-53.

Ginevičius, R.; Podviezko, A. 2013. The evaluation of financial stability and soundness of Lithuanian banks, Economic Research 26(2): 191-208.

Hays, F. H.; DeLurgio, S. A.; Gilbert Jr., A. H. 2009. Concentration, the internet and pricing of bank assets and liabilities, Research in Business and Economics Journal 1: 1-13.

Hegazy, M.; Hegazy, S. 2012. The development of key financial performance indicators for UK construction companies, Accounting, Accountability \& Performance 17(1-2): 49-77.

Hofmann, E.; Lampe, K. 2012. Financial statement analysis of logistics service providers: ways of enhancing performance, International Journal of Physical Distribution \& Logistics Management 43(4): 321-342. http://dx.doi.org/10.1108/IJPDLM-08-2012-0229

Hon, J.-S.; Chu, S.-J. 2011. Performance assessment between Taiwan and Korea TFT-LCD panel industry from a risk and return perspective before and after global financial crisis, International Journal of Electronic Business Management 9(2): 81-94.

Hosseini, S.-H.; Ezazi, M. E.; Heshmati, M. R.; Hosseini Moghadam, S.-M. R. 2013. Top companies ranking based on financial ratio with AHP-TOPSIS combined approach and indices of Tehran Stock Exchange, International Journal of Economics and Finance 5(3): 126-133.

http://dx.doi.org/10.5539/ijef.v5n3p126

Hsu, L.-C. 2013. Investment decision making using a combined factor analysis and entropy-based TOPSIS model, Journal of Business Economics and Management 14(3): 448-466.

http://dx.doi.org/10.3846/16111699.2011.633098

Kendall, M. 1970. Rank correlation methods. 4th ed. London: Charles Griffin and Company.

Kotane, T.; Kuzmina-Merlino, I. 2012. Assessment of financial indicators for evaluation of business performance, European Integration Studies 6: 216-224.

Kowalski, T. 2012. The economic and monetary union countries vs. the global crisis, Poznan University of Economics Review 12(2): 19-48.

Lakštutienè, A.; Krušinskas, R.; Platenkovienè, J. 2011. Economic cycle and credit volume interaction: case of Lithuania, Engineering Economics 22(5): 468-476.

Li, X.; Roca, P. S.; Papaoikonomou, E. 2011. SMEs' responses to the financial and economic crisis and policy implications: an analysis of agricultural and furniture sectors in Catalonia, Spain, Policy Studies 32(4): 397-412. http://dx.doi.org/10.1080/01442872.2011.571856

Norvaišienè, R. 2012. The impact of capital structure on the performance efficiency of Baltic listed companies, Engineering Economics 23(5): 505-516.

Opricovic, S.; Tzeng, G. 2004. Compromise solution by MCDM methods: a comparative analysis 
of VIKOR and TOPSIS, European Journal of Operational Research 156: 445-455. http://dx.doi.org/10.1016/S0377-2217(03)00020-1

Podvezko, V. 2011. The comparative analysis of MCDA methods SAW and COPRAS, Inzinerine Ekonomika - Engineering Economics 22(2): 134-146.

Punniyamoorthy, M.; Murali, R. 2008. Balanced score for the balanced scorecard: a benchmarking tool, Benchmarking: an International Journal 15(4): 420-443.

Romanova, I. 2012. Bank lending and crisis: case of Latvia, Journal of Business Management 5: 87-97.

Soininen, J.; Puumalainen, K.; Sjogren, H. 2012.The impact of global economic crisis on SMEs. Does entrepreneurial orientation matter?, Management Research Review 35(10): 927-944.

http://dx.doi.org/10.1108/01409171211272660

Statistics Lithuania. 2013. Official Statistics Portal [online], [cited 9 March 2013]. Available from Internet: http://www.stat.gov.lt/en/

Šaparauskas, J.; Zavadskas, E. K.; Turskis, Z. 2011. Selection of façade's alternatives of commercial and public buildings on multiple criteria, International Journal of Strategic Property Management 15(2): 189-203. http://dx.doi.org/10.3846/1648715X.2011.586532

Thao, T. P.; Daly, K.; Ellis, C. 2013. Transmission of the global financial crisis to the East Asian, International Journal of Economics and Finance 5(5): 171-183.

http://dx.doi.org/10.5539/ijef.v5n5p171

Uslay, C.; Altintig, Z. A.; Winsor, R. D. 2010. An empirical examination of the "rule of three": strategy implications for top management, marketers, and investors, Journal of Marketing 74: 20-39. http://dx.doi.org/10.1509/jmkg.74.2.20

Yap, B. C.-F.; Yong, D. G.-F.; Poon, W.-C. 2010. How well do financial ratios and multiple discriminant analysis predict company failures in Malaysia, International Research Journal of Finance and Economics 54: 166-175.

Yiannaki, S. M. 2012. A systemic risk management model for SMEs under financial crisis, International Journal of Organizational Analysis 20(4): 406-422.

http://dx.doi.org/10.1108/19348831211268607

Zavadskas, E. K.; Kaklauskas, A.; Turskis, Z.; Tamošaitienė, J. 2008. Selection of the effective dwelling house walls by applying attributes values determined at intervals, Journal of Civil Engineering and Management 14(2): 85-93. http://dx.doi.org/10.3846/1392-3730.2008.14.3

Zelgalve, E.; Zaharcenko, A. 2012. Transformation of the role of financial analysis in enterprise management, Management of Organizations: Systematic Research 64: 147-167.

\footnotetext{
Algirdas KRIVKA was born in 1982 in Lithuania. In 2004 he received a Bachelor of Economics, in 2006 - Master of Economics (Finance specialization), in 2010 - Doctor of Social Sciences (Economics). Associate Professor at the Department of Economics and Management of Enterprises, Faculty of Business Management, Vilnius Gediminas Technical University since 2011. Research interests: market structures, industry analysis, oligopoly, competitive strategies.
} 